\title{
Penggunaan Aplikasi Media Sosial Berbasis Audio Visual dalam Membentuk Konsep Diri (Studi Kasus Aplikasi Tiktok)
}

\author{
Dian Novita Sari Chandra Kusuma, Roswita Oktavianti \\ Dian.915160169@stu.untar.ac.id,roswitao@fikom.untar.ac.id \\ Fakultas Ilmu Komunikasi Universitas Tarumanagara
}

\begin{abstract}
TikTok social media is popular with various groups and age groups. TikTok is an audio visual based social media application that contains short videos that are homemade or made by other people who entertain with interesting features such as the latest music, unique face filters and others. This study uses the Theory of Uses and Gratifications to determine individual satisfaction in using TikTok social media. Social media can shape the self-concept of its users based on internal factors (physical and psychological) and external factors (other people and reference groups). This study aims to find out how the use of audio visualbased social media in shaping the self-concept of users with different age levels. This study uses a qualitative approach with a case study method for users of TikTok social media. Data collection was carried out using observations and interviews with 4 sources of users of TikTok applications who have different age levels. The results of this study indicate differences in the age level of TikTok users affect the duration of using the application also affect the formation of self-concept formed by the speakers. The use of the TikTok application forms the self-concept of the resource person in a positive direction such as increasing the confidence of the resource person to show his identity and negative selfconcepts such as lack of time management.
\end{abstract}

Keywords: social media, uses and gratifications, self-concept.

\begin{abstract}
Abstrak
Media sosial TikTok digemari oleh berbagai kalangan dan jenjang umur. TikTok adalah aplikasi media sosial berbasis audio visual yang berisikan video-video pendek buatan sendiri maupun buatan orang lain yang menghibur dengan fitur-fitur menarik seperti musik terbaru, filter wajah yang unik dan lain-lain. Penelitian ini menggunakan Teori Uses and Gratifications untuk mengetahui kepuasan individu dalam menggunakan media sosial TikTok. Media sosial dapat membentuk konsep diri dari penggunanya berdasarkan faktor internal (fisik dan psikis) dan faktor eksternal (orang lain dan kelompok rujukan). Penelitian ini bertujuan untuk mengetahui bagaimana penggunaan media sosial berbasis audio visual dalam membentuk konsep diri penggunanya dengan jenjang umur yang berbeda. Penelitian ini menggunakan pendekatan kualitatif dengan metode studi kasus terhadap pengguna media sosial TikTok. Pengumpulan data dilakukan menggunakan observasi dan wawancara kepada 4 narasumber pengguna aplikasi TikTok yang memiliki jenjang umur yang berbeda. Hasil dari penelitian ini menunjukkan perbedaan jenjang umur pengguna TikTok mempengaruhi durasi dalam menggunakan aplikasi juga mempengaruhi pembentukan konsep diri yang dibentuk oleh narasumber. Penggunaan aplikasi TikTok membentuk konsep diri narasumber ke arah positif seperti meningkatkan kepercayaan diri narasumber untuk menunjukkan jati dirinya dan konsep diri negatif seperti kurangnya dalam mengatur waktu.
\end{abstract}

Kata Kunci: media sosial, uses and gratifications, konsep diri.

\section{Pendahuluan}


Aplikasi media sosial saat ini memberikan wadah bagi masyarakat untuk saling bersosialisasi tanpa harus bertemu dan efisien waktu dalam berkomunikasi, sehingga internet merupakan media yang saat ini banyak digunakan untuk memuaskan kebutuhan manusia.

Teori Uses and Gratifications merupakan teori yang menyatakan bahwa individu menggunakan sebuah media massa dengan tujuan tertentu. media berusaha untuk memenuhi motif individu dalam menggunakan media massa, kebutuhan individu akan terpenuhi apabila motif dari individu telah terpenuhi. Sehingga media yang efektif merupakan media yang mampu memenuhi kebutuhan individu (Kriyantono, 2014:208).

Kepuasan yang dicari oleh tiap individu akan berbeda-beda sesuai dengan konsep diri yang dibentuk. William D Brooks menyatakan bahwa konsep diri merupakan pengetahuan dan penilaian mengenai diri kita. Pandangan tentang diri ini dapat bersifat psikologis, sosial dan fisik (dalam Widiarti, 2017:137).

Salah satu aplikasi media sosial berbasis audio visual yang banyak diminati saat ini adalah TikTok. Aplikasi TikTok banyak diminati oleh remaja karena menghibur, juga membantu meningkatkan kreativitas dalam mengedit dan membuat sebuah konten video yang menarik perhatian publik, tetapi tak jarang juga aplikasi ini membuat para remaja menjadi lupa akan waktu dan tempat dalam menggunakannya. Aplikasi ini pun membuat penggunanya menjadi berlomba-lomba untuk viral, bahkan demi mendapatkan respon dan likes yang banyak, mereka rela melakukan hal apa saja. Aplikasi TikTok tidak hanya menarik perhatian anak remaja melainkan orang dewasa. Saat ini pengguna TikTok juga berasal dari selebriti lokal dan mancanegara bahkan pejabat dan beberapa perusahaan juga menggunakan aplikasi audio visual ini. Hal ini yang kemudian membuat peneliti tertarik untuk meneliti "Penggunaan Aplikasi Media Sosial Berbasis Audio Visual Dalam Membentuk Konsep Diri".

Rumusan masalah pada penelitian ini adalah bagaimana penggunaan aplikasi media sosial berbasis audio visual dalam membentuk konsep diri? Penelitian ini bertujuan untuk mengetahui penggunaan aplikasi media sosial berbasis audio visual dalam membentuk konsep diri.

Teori Uses and Gratifications merupakan teori yang menyatakan bahwa individu menggunakan sebuah media massa dengan tujuan tertentu. media berusaha untuk memenuhi motif individu dalam menggunakan media massa, kebutuhan individu akan terpenuhi apabila motif dari individu telah terpenuhi. Sehingga media yang efektif merupakan media yang mampu memenuhi kebutuhan individu (Kriyantono, 2014:208). Gratification Sought (GS) merupakan pemenuhan kebutuhan yang dicari untuk mencapai suatu kepuasaan yang diinginkan oleh individu pada saat akan menggunakan media massa tertentu. Gratification sought merupakan motif seseorang yang mendorong dalam menggunakan suatu media. Sedangkan Gratification Obtained (GO) merupakan pemenuhan kebutuhan yang dicari untuk mencapai suatu kepuasaan yang diinginkan oleh individu pada saat setelah menggunakan media massa tertentu. GO terbentuk dari kepuasan nyata yang telah diperoleh individu pada saat menggunakan media dan evaluasi mengenai isi media (Kriyantono, 2014:210-211).

Menurut Brook, konsep diri merupakan sebuah pengamatan dan rasa emosional individu terhadap dirinya, persepsi akan diri memiliki sifat seperti faktor fisik, faktor sosial dan faktor psikologi yang berisikan apa yang ada di pikiran dan apa yang di 
rasakan seseorang tentang dirinya sendiri (dalam Hayati, 2018:11). Beberapa hal yang mempengaruhi konsep diri menurut Rakhmat ada dua faktor, yaitu:

1) Orang Lain

Harry Stack menjelaskan bahwa jika kita dihormati, diterima dan dihargai oleh orang lain di karenakan kondisi diri, maka diri biasanya akan bersikap menghormati dan menghargai diri sendiri. Sebaliknya, jika orang lain meremehkan, memberi balasan yang negatif dan menolak kita, maka diri kita akan beranggapan negatif akan diri sendiri.

2) Kelompok Rujukan

Semua kelompok memiliki ketentuan tersendiri. Ada kelompok yang mengikat secara emosional dan memiliki pengaruh pada pembentukan konsep diri, hal ini disebut kelompok rujukan. Dengan melihat kelompok ini, orang akan menyesuaikan perilakunya dirinya dengan karakteristik yang dimiliki kelompoknya (dalam Widiarti, 2017:139).

Menurut Dariyo (2011:202), konsep diri memiliki dua aspek, pertama yaitu aspek fisiologis, aspek ini mencakup fisik, warna kulit, bentuk/berat badan, wajah (tampan/cantik, biasa atau jelek), memiliki jasmani yang sehat, normal/cacat dan sebagainya. Fisik seseorang dapat mempengaruhi seseorang dalam menilai diri sendiri, dan juga biasanya orang lain pun menilai seseorang diawali dengan menilai terhadap fisik. Aspek Psikologis, aspek psikologis meliputi tiga hal yaitu, kognisi (pengetahuan, hobi dan bakat, ide kreatif, teliti), afeksi (daya tahan, rajin, dan pekerja keras, kompetitif, tingkat kontrol diri), konasi (kecepatan dan ketelitian kerja, coping stres, resiliensi). Aspek Psiko-sosiologis, merupakan pengertian individu yang mempunyai koneksi terhadap lingkungan bersosialisasi. Terdapat tiga unsur dalam aspek psiko-sosiologis yaitu, orangtua, saudara, kerabat, teman-teman sosial dan tetangga.

\section{Metode Penelitian}

Pendekatan yang digunakan peneliti pada penelitian ini adalah pendekatan kualitatif. Sugiyono (2014:1) mengatakan, penelitian kualitatif merupakan penelitian yang digunakan untuk meneliti pada kondisi objek nyata yang bersifat alamiah (sebagai lawannya adalah eksperimen) dimana peneliti sebagai instrumen kunci, teknik pengumpulan data dilakukan secara triangulasi (gabungan), analisis data bersifat induktif dan hasil penelitian kualitatif lebih menekankan makna pada generalisasi. Metode penelitian yang digunakan oleh peneliti adalah studi kasus. Studi kasus menurut Creswell adalah penelitian yang digunakan terhadap suatu objek yang disebut kasus, yang dilakukan secara seutuhnya, menyeluruh dan mendalam dengan menggunakan berbagai macam sumber data (dalam Gunawan, 2014:114). Penelitian ini meneliti studi kasus terhadap pengguna aplikasi TikTok.

Subjek dari penelitian ini adalah empat informan yaitu pengguna TikTok yang memiliki perbedaan jenjang umur yakni pelajar SMP, SMA, Mahasiswa dan pekerja.

Objek dari penelitian ini adalah konsep diri yang terbentuk dari penggunaan aplikasi berbasis audio visual, TikTok. Terbentuknya Konsep diri dari penggunaan aplikasi berbasis audio visual dapat berasal dari orang lain (eksternal) dan dari diri sendiri (internal).

Pada penelitian ini menggunakan observasi terstruktur. Observasi terstruktur merupakan penelitian yang telah dibuat secara terperinci tentang apa yang akan diteliti, lokasi penelitian dan lainnya. Observasi terstruktur digunakan jika peneliti 
memahami secara jelas mengenai variabel yang akan diteliti. Pedoman wawancara terstruktur atau angket tertutup dapat juga dilakukan untuk melakukan penelitian. Unit observasi pada penelitian ini adalah akun TikTok narasumber, sebagai berikut:

a. Narasumber 1 (Viona Angreany, siswa SMP, usia 15 tahun) :

Nama akun TikTok Viona adalah Vionaangreany. Pada akun TikToknya narasumber memiliki 18 video postingan dengan 92 likes.

b. Narasumber 2 (Ellisa siswa SMA, usia 17 tahun)

Nama akun TikTok Ellisa adalah Ellisate. Pada akun TikToknya narasumber memiliki 73 video postingan dengan 822 likes.

c. Narasumber 3 (Andi Setiawan, mahasiswa, usia 21 tahun)

Nama akun TikTok Andi adalah phengphi. Pada akun TikToknya narasumber memiliki 4 video postingan dengan 8 likes.

d. Narasumber 4 (Erna Wati, pekerja, usia 36 tahun)

Nama akun TikTok ibu Erna adalah BUNDA MAURIEN. Pada akun TikToknya narasumber memiliki 443 video postingan dengan 16.900 likes.

\section{Hasil Penemuan dan Diskusi}

\section{Penggunaan Media}

Semua narasumber merupakan pengguna media sosial berbasis audio visual, TikTok dengan sangat aktif. Rata-rata mereka menggunakan aplikasi TikTok setiap harinya, namun terdapat perbedaan dalam durasi pemakaian dari setiap narasumber. Pada narasumber 1 dan 2 yang merupakan siswi SMP dan SMA, mereka menggunakan aplikasi TikTok dengan durasi yang lebih sedikit dibandingkan narasumber 3 dan 4 yang merupakan mahasiswa dan pekerja. Hal ini dikarenakan pelajar SMP dan SMA masih diawasi oleh orang tuanya dalam menggunakan gadget dan juga mereka masih mengikuti kegiatan sekolah online yang banyak memberikan tugas di rumah, sedangkan mahasiswa dan pekerja sangat sering menggunakan aplikasi TikTok tanpa batasan waktu.

Menurut DeFleur, teori kategori sosial adalah perkembangan masyarakat yang menyebabkan terbentuknya kategori sosial berdasarkan karakteristik demografik individu (umur, pendidikan, pendapatan, dan lain-lain). Asumsi dari teori kategori sosial adalah orang dengan usia dan jenis kelamin yang sama cenderung sama pula dalam merespon pesan yang disampaikan oleh media massa. Menurut teori kategori sosial, respon setiap orang dalam menerima terpaan media tergantung dari faktor demografi seperti usia, jenis kelamin, dan tingkat pendidikan.

Hal ini membuktikan bahwa teori kategori sosial sejalan dengan penelitian yang telah dilakukan oleh Oktaviani dan Fatchiya (2019:23-24), dimana menurutnya efektifitas penggunaan media sosial dan keefektifitasan promosi dipengaruhi oleh faktor demografis (usia, jenis pekerjaan, tingkat pendidikan, motivasi, jangkauan geografis dan tingkat pengeluaran).

Teori Uses and Gratifications merupakan teori yang menyatakan bahwa individu menggunakan sebuah media massa dengan tujuan tertentu. media berusaha untuk memenuhi motif individu dalam menggunakan media massa, kebutuhan individu akan terpenuhi apabila motif dari individu telah terpenuhi. Sehingga media yang efektif merupakan media yang mampu memenuhi kebutuhan individu (Kriyantono, 2014:208). Gratification Sought (GS) 
merupakan pemenuhan kebutuhan yang dicari untuk mencapai suatu kepuasaan yang diinginkan oleh individu pada saat akan menggunakan media massa tertentu. Gratification sought merupakan motif seseorang yang mendorong dalam menggunakan suatu media (Kriyantono, 2014:210-211).

Dari hasil jawaban narasumber, diketahui narasumber aktif dalam menggunakan aplikasi TikTok untuk memenuhi harapan sosial yang berasal dari teman dan harapan psikis yaitu untuk menghibur diwaktu luang.

\section{Konsep Diri}

Pembentukan konsep diri dipengaruhi oleh dua faktor yaitu:

\section{a. Faktor Internal}

Dari faktor fisik, narasumber 1 dan narasumber 2 yang merupakan siswi SMP dan SMA menilai dirinya secara positif dan menganggap fisiknya menarik. Alasan mereka merasa dirinya menarik karena faktor pujian dan rasa percaya diri. Sedangkan narasumber 3 dan 4 menilai dirinya biasa saja karena tidak suka melebih-lebihkan diri dan mengurangi penilaian akan fisiknya. Hal ini menunjukkan alasan narasumber mengunggah video ke TikTok bukan karena fisik melainkan karena ingin mendapatkan hiburan.

Dari faktor psikis, semua narasumber merasa terhibur dan puas setelah menggunakan aplikasi TikTok juga setelah mengunggah video ke TikTok dan mereka juga merasa kreatifitasnya semakin meningkat. Semua narasumber menanggapi komentar buruk dengan menjadikan komentar tersebut pembelajaran untuk kedepannya. Hal ini memperlihatkan bahwa konsep diri yang dibentuk lewat aplikasi TikTok lebih mengarahkan narasumber ke arah yang lebih baik tetapi tak lepas dari dampak positif, TikTok juga memberikan dampak negatif kepada kepribadian narasumber seperti kurang menghargai waktu.

Menurut Dariyo (2011:202), konsep diri memiliki dua aspek, pertama yaitu aspek fisiologis, aspek ini mencakup fisik, warna kulit, bentuk/berat badan, wajah (tampan/cantik, biasa atau jelek), memiliki jasmani yang sehat, normal/cacat dan sebagainya. Fisik seseorang dapat mempengaruhi seseorang dalam menilai diri sendiri, dan juga biasanya orang lain pun menilai seseorang diawali dengan menilai terhadap fisik. Aspek Psikologis, aspek psikologis meliputi tiga hal yaitu, kognisi (pengetahuan, hobi dan bakat, ide kreatif, teliti), afeksi (daya tahan, rajin, dan pekerja keras, kompetitif, tingkat kontrol diri), konasi (kecepatan dan ketelitian kerja, coping stres, resiliensi).

Alasan narasumber menggunakan aplikasi TikTok inipun karena dorongan sosial yang berasal dari teman. Dalam pemanfaatan aplikasi TikTok narasumber banyak menggunakan aplikasi ini sebagai media komunikasi untuk mencari teman baru ataupun mempererat hubungan dengan teman dekat. Hal ini sejalan dengan penelitian terdahulu Azeharie (2014), yang meneliti Analisis Penggunaan Twitter Sebagai Media Komunikasi Selebritis Di Jakarta. Azeharie mengatakan bahwa media sosial Twitter merupakan media yang sangat efektif untuk selebriti berkomunikasi dengan penggemarnya, yang berarti media sosial saat ini dimanfaatkan sebagai media komunikasi yang efektif terhadap individu lainnya.

\section{b. Faktor Eksternal}


Dari faktor orang lain, orang lain juga dapat mempengaruhi penilaian diri dari narasumber. Semua narasumber lebih suka menjadikan komentar negatif dari orang yang tidak dikenal sebagai pembelajaran untuk menciptakan konten-konten yang lebih baik nantinya.

Dari faktor kelompok rujukan, narasumber 1 dan 2 yang merupakan siswi SMP dan SMA pernah mendapati orang tua dan temannya berkomentar buruk dan baik kepada dirinya karena menggunakan aplikasi TikTok, sedangkan narasumber 2 dan 3 yang merupakan mahasiswa dan pekerja lebih banyak menerima komentar negatif dari teman-temannya karena menggunakan aplikasi TikTok. Tanggapan mereka dengan komentar dari orang tua ataupun teman yang menyukai ataupun tidak menyukai mereka menggunakan aplikasi TikTok adalah menerima apabila komentar yang diberikan masih bisa diterima dan tidak peduli apabila komentar yang diberikan terlalu berlebihan.

Menurut Rakhmat (dalam Widiarti, 2017:139), beberapa hal yang mempengaruhi konsep diri ada dua faktor, yaitu faktor orang lain dijelaskan bahwa jika kita dihormati, diterima dan dihargai oleh orang lain di karenakan kondisi diri, maka diri biasanya akan bersikap menghormati dan menghargai diri sendiri. Sebaliknya, jika orang lain meremehkan, memberi balasan yang negatif dan menolak kita, maka diri kita akan beranggapan negatif akan diri sendiri. Faktor dari kelompok rujukan adalah semua kelompok memiliki ketentuan tersendiri. Ada kelompok yang mengikat secara emosional dan memiliki pengaruh pada pembentukan konsep diri, hal ini disebut kelompok rujukan. Dengan melihat kelompok ini, orang akan menyesuaikan perilakunya dirinya dengan karakteristik yang dimiliki kelompoknya.

Dari rangkuman mengenai konsep diri di atas peneliti mendapati bahwa faktor fisik tidak mempengaruhi narasumber menggunakan ataupun mengunggah video ke TikTok. Narasumber menggunakan aplikasi TikTok lebih karena faktor psikis yang melibatkan perasaan puas dan senang karena menggunakan aplikasi ini. Faktor orang lain dan kenalan yang memberikan komentar saat menggunakan aplikasi TikTok mempengaruhi penilaian akan diri mereka menjadi lebih baik ataupun lebih buruk. Hal ini sejalan dengan penelitian yang dilakukan oleh Nurhaini (2018) yang menyatakan bahwa terdapat pengaruh konsep diri dan kontrol diri dengan perilaku konsumtif terhadap gadget pada remaja SMAN 1 Tanah Grogot, yang juga sejalan dengan penelitian terdahulu Hayati (2018) yang menyatakan bahwa terdapat pengaruh dalam pembentukan konsep diri anak-anak pengguna aktif media sosial

Gratification Obtained (GO) merupakan pemenuhan kebutuhan yang dicari untuk mencapai suatu kepuasaan yang diinginkan oleh individu pada saat setelah menggunakan media massa tertentu. GO terbentuk dari kepuasan nyata yang telah diperoleh individu pada saat menggunakan media dan evaluasi mengenai isi media (Kriyantono, 2014:210-211). Dari hasil jawaban narasumber diketahui bahwa terdapat rasa puas dari menggunakan aplikasi TikTok. Hal ini bermula dari kebutuhan mereka untuk mengisi waktu senggang dengan hiburan dan dorongan dari sosial. Narasumber memilih aplikasi TikTok karena menurut mereka menarik dan sangat menghibur, setelah menggunakan aplikasi TikTok semua narasumber merasakan perasaan puas dan senang karena kebutuhan yang mereka inginkan terpenuhi dari penggunaan aplikasi TikTok. 
Dian Novita Sari Chandra Kusuma, Roswita Oktavianti: Penggunaan Aplikasi Media Sosial Berbasis Audio Visual dalam Membentuk Konsep Diri (Studi Kasus Aplikasi Tiktok)

\section{Simpulan}

Penggunaan media sosial berbasis audio visual, TikTok diminati oleh semua jenjang usia. Usia mempengaruhi durasi pemakaian dari aplikasi TikTok, semakin kecil usia semakin terbatas durasi dalam menggunakan aplikasi TikTok dan sebaliknya. Hal ini dikarenakan masih adanya pengawasan dari orang tua maupun tugas sekolah yang membatasi mereka dalam menggunakan aplikasi TikTok. Aplikasi TikTok memberikan kepuasan sosial dan hiburan terhadap penggunanya dengan fitur yang mudah digunakan. Pada narasumber dengan jenjang usia muda mereka menggunakan aplikasi TikTok untuk mengikuti perkembangan sosial, sedangkan narasumber dengan jenjang usia yang lebih dewasa mereka menggunakan aplikasi TikTok untuk mengisi waktu luang.

Dalam pemanfaatannya, aplikasi TikTok dapat mempengaruhi pembentukan konsep diri dari penggunanya. Dari komentar positif narasumber mendapatkan kepercayaan diri dan dari komentar negatif narasumber membentuk mental yang kuat dalam menanggapi komentar tersebut sebagai pembelajaran. Aplikasi ini membentuk konsep diri pengguna ke arah yang baik seperti memberikan kreatifitas dan wawasan kepada penggunannya dalam mengedit, membuat konten, mendapat ilmu menari dan memasak. Aplikasi ini juga membentuk konsep diri penggunanya ke arah yang buruk, seperti kurangnya dalam mengatur waktu.

\section{Ucapan Terima Kasih}

Peneliti ingin menyampaikan rasa terima kasih kepada semua pihak yang ikut terlibat dan telah membantu peneliti selama proses penelitian ini berlangsung, yaitu kepada seluruh narasumber yang telah memberikan kesediaan untuk bekerjasama selama proses penelitian ini.

\section{Daftar Pustaka}

Azeharie, Suzy. (2014). Analisis Penggunaan Twitter Sebagai Media Komunikasi Selebritis di Jakarta. Jurnal Komunikasi, 6 (2), 97. Maret 3, 2020. Terarsip di: https://journal.untar.ac.id/index.php/komunikasi/article/view/35/17.

Dariyo, Agoes. (2011). Psikologi Perkembangan Anak Tiga Tahun Pertama. Bandung: PT Refika Aditama.

Gunawan, Imam. (2014). Metode Penelitian Kualitatif Teori \& Praktek. Jakarta: PT Bumi Aksara.

Hayati, Laila. (2018). Konsep Diri Anak-anak Pengguna Aktif Media Sosial. Jurnal Sosiologi, 6 (2), 11. Maret 3, 2020. Terarsip di: https://www.researchgate.net/publication/329990247_Konsep_Diri_Anakanak_Pengguna_Aktif_Media_Sosial

Kriyantono, Rachmat. (2014). Teknik Praktis Riset Komunikasi. Jakarta: Prenada Media Group.

Nurhaini, Dwi. (2018). Pengaruh Konsep Diri dan Kontrol Diri Dengan Perilaku Konsumtif Terhadap Gadget Remaja SMAN 1 Tanah Grogot. Jurnal Psikologi, 6 (1), 221. Maret 3, 2020. Terarsip di: http://ejournal.psikologi.fisip-unmul.ac.id/site/wpcontent/uploads/2018/08/JURNAL\%20DWI\%20NURHAINI\%20(08-27-1801-58-25).pdf 
Oktaviani, Wanda F., \& Fatchiya, Anna. (2019). Efektivitas Penggunaan Media Sosial sebagai Media Promosi Wisata Umbul Ponggok, Kabupaten Klaten. Jurnal Komunikasi Pembangunan, 17 (1), 24-24. Mei 9, 2020. Terarsip di: https://journal.ipb.ac.id/index.php/jurnalkmp/article/view/26586

Rasika, Ira A. (2013). Pengaruh Terpaan Pemberitaan Teror di Surakarta dan Faktor Demografi (Usia, Jenis Kelamin, Tingkat Pendidikan) Terhadap Citra Polisi. Jurnal Interaksi Online, 1 (3). Mei 9, 2020. Terarsip di: https://ejournal3.undip.ac.id/index.php/interaksi-online/article/view/2700

Sugiyono. (2014). Metode Penelitian Pendidikan Pendekatan Kuantitatif, Kualitatif, dan $R \& D$. Bandung: Alfabeta.

Widiarti, Pratiwi W. (2017). Konsep Diri (Self Concept) Dan Komunikasi Interpersonal Dalam Pendampingan Pada Siswa SMP Se Kota Yogyakarta. Jurnal Komunikasi, 47 (1), 137,139. Februari 24, 2020. Terarsip di: https://journal.uny.ac.id/index.php/informasi/article/view/15035/0 